\title{
DETEKSI FINANCIAL STATEMENT FRAUD DENGAN ANALISIS FRAUD TRIANGLE PADA PERUSAHAAN ANEKA INDUSTRI YANG TERDAFTAR DI BURSA EFEK INDONESIA PERIODE 2012- 2015"
}

\author{
Muhammad Saiful ${ }^{1}$ \\ Alumni Fakultas Ekonomi Universitas Maritim Raja Ali Haji \\ H. Achmad Uzaimi² (achmad_uzaimi@umrah.ac.id) \\ Fakultas Ekonomi Universitas Maritim Raja Ali Haji \\ Asri Eka Ratih ${ }^{3}$ (asriekaratih@yahoo.co.id) \\ Fakultas Ekonomi Universitas Maritim Raja Ali Haji
}

\begin{abstract}
Tujuan dari penelitian ini adalah untuk menganalisis faktor-faktor yang mempengaruhi implikasinya terhadap kecurangan laporan keuangan. Tahap regresi linier berganda untuk menguji pengaruh analisis faktor-faktor yang mempengaruhi kecurangan laporan keuangan. Populasi penelitian ini adalah laporan keuangan berbagai perusahaan industri yang terdaftar di Bursa Efek Indonesia pada tahun 2012-2015. Teknik pengambilan sampel adalah metode purposive sampling yang menghasilkan 13 sampel pada tahun 20122015. Hasil penelitian ini menunjukkan bahwa pada model regresi pertama menunjukkan variabel tekanan yaitu financial leverage, financial target, dan capital berpengaruh terhadap kecurangan laporan keuangan. Sedangkan variabel tekanan adalah stabilitas keuangan, variabel peluang adalah sifat industri, dan pemantauan yang efektif, variabel rasionalisasi adalah audit opini tidak mempengaruhi kecurangan laporan keuangan perusahaan.
\end{abstract}

Kata kunci: Stabilitas Keuangan, Leverage, Sasaran Keuangan, Perputaran Modal

\section{PENDAHULUAN}

Selama hampir satu dekade belakangan ini terdapat dua jenis kejahatan yang menggemparkan dunia.Dua jenis kejahatan tersebut adalah terorisme dan kejahatan keuangan berupa fraud (kecendrungan kecurangan akuntansi).Salah satu kejahatan fraud (kecendrungan kecurangan akuntansi) yang sangat dikenal yaitu kasus Enron Inc (symbol saham New York Stock Exchange) pada tahun 2001. Kebangkitan dan kemajuan Enron dapat dikatakan sangat cepat, secepat pula dengan kejatuhannya karena melakukan tindak fraud yang membawa kerugian kepada pemegang saham Enron, kreditur, pegawai dan rekan Enron serta pula menjatuhkan Arthur Andersen yang menjadi Auditor Independen atas laporan keuangan Enron yang sebenarnya Andersen saat itu merupakan kantor akuntan publik terbesar didunia. Selain kasus Enron Inc pada tahun 2011 terjadi pula Fraud yang dilakukan Sino-forest Corp di Cina perusahaan ini berdiri tahun 1994. Tahun 2011 dituduh melakukan fraud dan diselidiki oleh Royal Canadian Mounted Police dan Ontarino Securities Commision. 30 Maret 2012 Sino-forest mengajukan bangkrut di Kanada karena Sino go public di Kanada dan mengumumkan akan dijual atau direstrukturisasi dengan hasilnya untuk membayar kreditur. Pemicunya adalah kejatuhan harga 
saham Sino Juni 2011 akibat terbitnya laporan yang negatif oleh Carson Block of Muddy Waters Research, yang menuduh Sino-forest fraud dengan meninggikan aset dan laba, serta penggelapan yang substansial.

Laporan keuangan diterbitkan untuk memberikan informasi keuangan mengenai posisi keuangan, kinerja keuangan dan arus kas perusahaan yang akan membantu bagi pihak pemegang kepentingan untuk membuat suatu keputusan ekonomi. Laporan keuangan yang tidak memberikan informasi dengan benar dan akurat akan menyesatkan para pengguna laporan keuangan dalam membuat keputusan. Akan tetapi, beberapa pihak pelaku bisnis melakukan fraud atau kecurangan dalam laporan keuangan untuk menampilkan gambaran kondisi keuangan yang terbaik sehingga dapat menarik keuntungan bagi perusahaan tersebut.

Penerbitan laporan keuangan secara umum bertujuan untuk memberikan informasi mengenai posisi keuangan, kinerja dan arus kas perusahaan.Pelaporan keuangan bermanfaat bagi sebagian besar kalangan pengguna laporan dalam rangka membuat keputusan- keputusan ekonomi serta menunjukan pertanggungjawaban manajemen atas penggunaan sumber- sumber daya yang dipercayakan kepada mereka (Ikatan Akuntan Indonesia 2007). Oleh karena itu pelaku bisnis harus dapat memberikan informasi yang akurat dan relevan serta terbebas dari adanya kecurangan (fraud) yang akan menyesatkan para pengguna laporan keuangan dalam proses pengambilan keputusan.

Kecurangan (fraud) merupakan suatu tindakan yang dilakukan secara disengaja dan itu dilakukan untuk tujuan pribadi atau orang lain, dimana tindakan tersebut adalah telah menyebabkan kerugian bagi pihak tertentu atau institusi tertentu. Kecurangan ini merupakan suatu tindakan yang sudah berada diluar koridor prinsip akuntansi yang berterima umum.Kecurangan mencakup tindakan ilegal yang sengaja dilakukan, lalu disembunyikan, dan memperoleh manfaat dengan melakukan pengubahan bentuk menjadi uang, kas, atau barang berharga lainnya.Tindakan ini dilakukan baik secara internal maupun eksternal, secara sengaja, dan disembunyikan.

Berkaitan dengan pelaporan keuangan, kecurangan diartikan sebagai tindakan yang sengaja dilakukan yang mengakibatkan salah saji materil dalam pelaporan keuangan (Generally Accepted Auditing Standard- GAAS, 2006 dikutip dalam Priantara 2013).Salah saji yang terdapat dalam laporan keuangan yang curang merupakan salah saji yang disengaja untuk menipu para pengguna laporan keuangan.Sumber dari salah saji ini meliputi manipulasi atau pemalsuan catatan akuntansi, salah saji atau penghilang yang disengaja dari laporan keuangan, dan/atau kesalahan penerapan prinsip akuntansi. Kecurangan pada laporan keuangan di satu sisi dapat memberikan keuntungan bagi para pelaku bisnis karena mereka dapat melebih- lebihkan hasil usaha (overstated) dan kondisi keuangan mereka sehingga laporan keuangan mereka terlihat baik dalam pandangan publik. Akan tetapi, meningkatnya kecurangan laporan keuangan laporan juga sangat merugikan publik yang sangat menggantungkan pengambilan keputusan mereka berdasarkan laporan keuangan tersebut.

Bagaimana permainan angka laporan keuangan dapat dicurangkan, dalam aktivitasnya perusahaan sudah dipastikan ingin mencapai tujuannya dengan sebaik- baiknya. Segala cara mungkin dilakukan manjemen perusahaan agar tujuannya dapat tercapai. Tujuan perusahaan yang utama tentunya adalah mencapai keuntungan yang maksimal dengan sumber daya yang terbatas.Pada perjalanannya tujuan perusahaan mungkin tidak tercapai dengan baik, bahkan perusahaan mungkin jadi bangkrut. Manajemen perusahaan dengan segala cara menginginkan kinerjanya dinilai baik. Kondisi perusahaan yang tidak sehat sering kali oleh manajemen ditutupi dengan menampilkan atau melaporkan kinerja keuangannya tetap baik. Akibat dari kondisi ini lah 
manajemen berkolusi dengan akuntan agar kinerjanya tetap bisa dinilai baik oleh para calon investor, pemilik atau pihak lain yang berkepentingan dengan kinerja perusahaan yang baik. Akuntan yang diminta oleh manajemen seringkali melakukan permainan angka yang akan membawa pembaca laporan keuangan menilai laporan keuangannya baik.

Terjadinya kecurangan yang tidak dapat terdeteksi, dapat memberikan efek yang merugikan dan cacat bagi proses pelaporan keuangan. Adanya kecurangan berakibat serius dan membawa banyak kerugian.Konsekuensinya adalah deteksi terhadap kecurangan menjadi isu penting.Kemampuan untuk melakukan indentifikasi kecurangan secara cepat menjadi suatu kebutuhan.Namun pendeteksian terhadap kecendrungan kecurangan akuntansi (fraud) tidak selalu mendapat titik terang karena berbagai motivasi yang mendasarinya serta banyaknya metode untuk menilai adanya kecurangan tersebut.

Menurut Priantara dalam bukunya tahun 2013 penyebab timbulnya fraud atas laporan keuangan distimulus oleh kepentingan manajemen eksekutif (direksi).Oleh karena itu pada dasarnya penyebab fraud ini disebabkan kelemahan Good Corporate Governance dan faktor personal manajemen atau pemegang saham diinternal organisasi atau peraturan beserta sanksi yang lemah atau tidak tegas ataupun tidak jelas.

Secara umum, kecurangan akan selalu terjadi jika tidak ada pencegahan dan pendeteksian. Menurut teori Cressey (dikutip oleh Priantara et al., 2013), terdapat tiga kondisi yang selalu hadir dalam tindakan fraud yaitu pressure, opportunity, dan rationalization yang disebut sebagai fraud triangle.

Berdasarkan latar belakang yang telah diungkapkan diatas maka penulis tertarik untuk melakukan penelitian mengenai "Deteksi Financial Statement Fraud Dengan Analisis Fraud Triangle Pada Perusahaan Aneka Industri Yang Terdaftar Di Bursa Efek Indonesia Periode 2012- 2015".

\section{LANDASAN TEORI}

Dalam literature akuntansi dan auditing, fraud diterjemahkan sebagai praktik kecurangan dan fraud sering diartikan sebagai irregularity atau ketidakteraturan dan penyimpangan.Terdapat banyak definisi dan pengertian fraud. Salah satunya adalah definisi menurut Black Law dalam Priantara et al, (2013)yaitu :The intentional use of deceit, a trick or some dishonest means to deprive another of his money, property or legal right, eithers as a cause of action or as a fatal element in the action itself.

Definisi fraud tersebut dapat diterjemahkan dan diartikan sebagai berikut: Suatu perbuatan sengaja untuk menipu atau membohongi, suatu tipu daya atau cara- cara yang tidak jujur untuk mengambil atau menghilangkan uang, harta, hak yang sah milik orang lain baik- baik karena suatu tindakan atau dampak yang fatal dari tindakan itu sendiri.

Sedangkan fraud menurut standar the institute of internal auditors tahun 2013, yaitu : Any illegal act characterized by deceit, concealment, or violation of trust. These acts are not dependent upon the threat of violence or physical force. Frauds are perpetrated by parties and organizations to obtain : money, property, or services; to advoid payment or loss of services; or to secure personal or business advantage. Yang dapat diartikan sebagai segala perbuatan yang dicirikan dengan pengelabuan atau pelanggaran kepercayaan untuk mendapatkan uang, aset, jasa atau mencegah pembayaran atau kerugian atau untuk menjamin keuntungan/ manfaat pribadi dan bisnis. Perbuatan ini tidak tergantung pada ancaman kekerasan oleh pelaku terhadap orang lain. 
Fraud itu sendiri sebenarnya merupakan suatu perbuatan melawan hukum yang dilakukan oleh orang- orang dari dalam dan atau luar organisasi, dengan maksud untuk mendapatkan keuntungan pribadi dan atau kelompoknya yang secara langsung merugikan pihak lain.

\section{Fraud Triangle (Segitiga Fraud)}

Konsep segitiga fraud (fraud triangle) saat ini digunakan secara luas dalam praktik Akuntan publik pada Statement of Auditing Standard (SAS) No. 99.Konsep ini bertumpu pada riset Donald Cressey (1953) dalam Diaz Priantara (2013) yang menyimpulkan bahwa fraud mempunya tiga sifat umum.Fraud triangle terdiri dari tiga kondisi yang umumnya hadir pada saat fraudterjadi : a) Insentif atau tekanan untuk melakukan fraud (pressure), b) Peluang atau kesempatan untuk melakukan fraud (opportunity), c) Dalih untuk membenarkan tindakan fraud (rationalization)

Cressey tertarik pada pelanggar kepercayaan yakni mereka yang melanggar kepercayaan atau amanah yang ditipkan kepada mereka. Cresseey secara khusus tertarik kepada godaan , karena alasan itu dalam penelitiannya, ia tidak menyertakan mereka yang memang mencari pekerjaan dengan tujuan mencuri. Dalam perkembangan selanjutnya hipotesa ini lebih dikenal sebagai fraud triangle.

a. Incentive/ pressure (Tekanan); Sisi pertama dari segitiga diberi judul pressure yang merupakan dorongan orang untuk melakukan fraud. Pada umumnya tekanan muncul karena kebutuhan atau masalah finansial, tapi banyak juga yang hanya terdorong oleh keserakahan. Penggelapan uang perusahaan oleh pelakunya bermula dari suatu tekanan kebutuhan keuangan yang mendesaknya yang menghimpit hidupnya.

b. Opportunity (Peluang/ Kesempatan); Opportunity adalah peluang yang memungkinkan terjadinya fraud. Para pelaku fraud percaya bahwa aktivitas mereka tidak akan terdeteksi. Dari ketiga elemen fraud triangle, kesempatan mengendalikan fraud terbesar adalah opportunity. Organisasi seharusnya peduli serta mampu untuk membangun sebuah proses, prosedur, dan kontrol serta tata kelola yang membuat semua personil dalam organisasi tidak memiliki kesempatan melakukan fraud dan yang efektif dapat mendeteksi fraud jika hal itu terjadi. Namun opportunity sangat berkaitan dengan integritas seseorang. Jika karyawan daalam perusahaan memiliki integritas yang rendah dan perusahaan tidak menerapkan pengendalian intern yang kuat sehinggga memunculkan kesempatan melakukan fraud maka risiko terjadinya fraud dalam perusahaan tersebut akan semakin tinggi, begitu pula sebaliknya.

c. Rationalization (Rasionalisasi); Rationalization terjadi karena seseorang mencari pembenaran atas aktifitasnya yang mengandung farud.Para pelaku fraud meyakini atau merasa bahwa tindakannya bukan merupakan suatu fraud tetapi adalah sesuatu yang memang merupakan haknya, bahkan kadang pelaku merasa telah berjasa karena telah berbuat banyak untuk organisasi.

Priantara (2013), segitiga fraud dari Cressey menjadi rujukan bagi profesi Akuntan Publik untuk merevisi pendekatan mengidentifikasi risiko dalam melaksanakan audit atas laporan keuangan. Konsep segitiga fraud dipakai untuk menjelaskan faktor risiko fraud.Faktor- faktor risiko yang berkaitan dengan penyajian secara salah laporan keuangan dalam nilai material atau signifikan.

a. Insentif atau Tekanan, stabilitas keuangan atau keuntungan terancam oleh situasi dan kondisi ekonomi, industri, politik, dan lain- lain termasuk terancam oleh situasi dan kondisi bisnis entitas yang bersangkutan seperti atau yang diindikasikan oleh tingkat kompetisi usaha yang sengit atau pasar berada pada titik jenuh yang diikuti oleh penurunan marjin 
keuntungan, penurunan yang signifikan pada permintaan pasar, arus kas negatif yang berulang- ulang dari operasi dan ketidakmampuan menghasilkan arus kas dari operasi sementara entitas melaporkan keuntungan atau pertumbuhan laba.

b. Peluang atau Kesempatan, sifat industri atau sifat operasionalnya entitas memberikan peluang untuk terlibat dalam fraudulent financial reporting, pemantauan manajemen yang tidak efektif, terdapat struktur organisasi yang tidak stabil atau kompleks, komponen pengendalian intern kurang memadai.

c. Sikap atau Rasionalitas, factor sikap factor sikap atau rasionalitas manajemen senior, anggota dewan pengarah (board of directors), atau pegawai yang menyebabkan mereka terlibat atau menjustifikasi fraudulent financial reporting, mungkin merupakan hal yang sulit atau yang tidak dapat dicurigai dengan mudah atau tidak mudah diobservasi oleh auditor.

\section{The M- Score}

Beneish (1999) M-Score adalah model matematika yang merumuskan beberapa rasio analisis dan terdiri dari delapan variabel untuk mengidentifikasi terjadinya penipuan keuangan atau kecenderungan untuk terlibat dalam mendapatkan manipulasi. Dan telah diperoleh hasil perhitungan Beneish $M$ Score yang telah kekal (robust), dengan indikasi jika lebih dari -2,22 diklasifikasikan sebagai perusahaan manipulator, bila kurang dari -2,22 diklasifikasikan sebagai perusahaan non-manipulator.

\section{METODOLOGI PENELITIAN}

\section{Definisi Dan Pengukuran Variabel}

Variabel dependen dalam penelitian ini adalah financial statement fraud (kecurangan laporan keuangan) yang diukur dengan menggunakan model Beneish $M$-Score. Beneish M-Score diukur dengan menggunakan 8 (delapan) rasio keuangan untuk mengidentifikasikan apakah perusahaan memiliki indikasi untuk memanipulasi pendapatan dalam laporan keuangan (Beneish, 1999).

$$
\begin{aligned}
\text { M Score }= & -4.84+0.920^{*} \mathrm{DSRI}+0.528^{*} \mathrm{GMI}+0.404^{\star} \mathrm{AQI}+0.892^{*} \mathrm{SGI}+0.115^{\star} \mathrm{DEPI} \\
& -0.172^{\star} \mathrm{SGAI}+4.679^{\star} \mathrm{TATA}-0.327^{\star} \mathrm{LEVI} \ldots \ldots \ldots \ldots \ldots \ldots \ldots \ldots \ldots \ldots \ldots \ldots \ldots \ldots \ldots \ldots \ldots \ldots \ldots \ldots \ldots \ldots \ldots \ldots \ldots \ldots
\end{aligned}
$$

Days' Sales in Receivables Index $(\mathrm{DSRI})=\frac{\text { net receivable } t / \text { sales } t}{\text { net receivable } t-1 / \text { sales } t-1}$

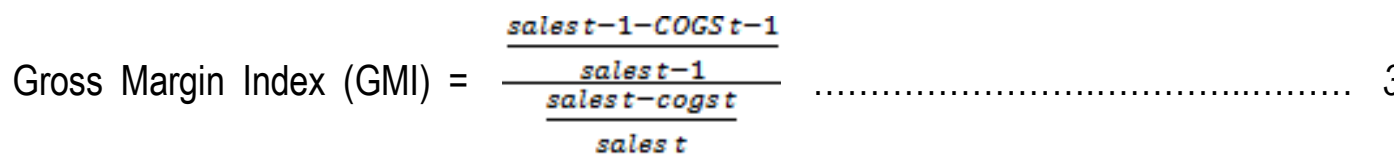

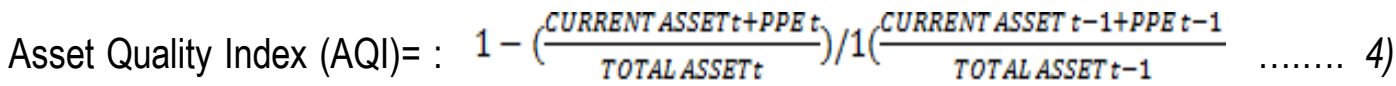

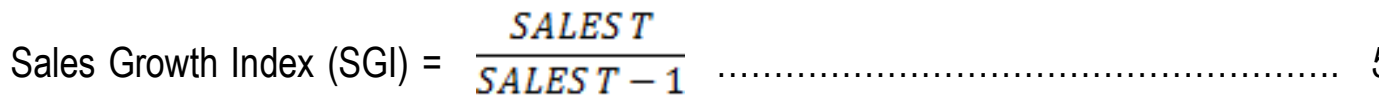

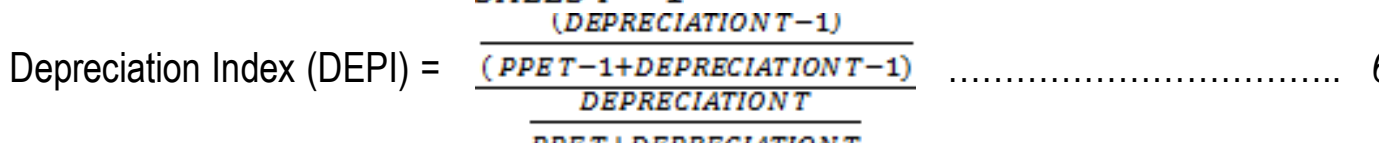


Sales, General and Administration Expenses Index (SGAI) $=\frac{\frac{\text { SGAEXPENSET }}{\frac{\text { SALEST }}{\text { SGAEXPENSET-1 }}}}{\text { SALEST }-1} \ldots . . .7$ )

Total Acrual to Total Assets $($ TATA $)=$ INCOME FROM OPRT - CASH FLOW FROM OPRT $\ldots . . . . .8)$

TOTALASET T

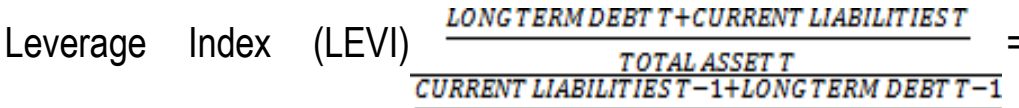

TOTAL ASSET T -1

\section{Pressure (Tekanan)}

Komponen Pressure (Tekanan) diukur melalui beberapa variabel, yaitu pertama Financial Stability (Stabilitas Keuangan). Financial Stability adalah keadaan yang menggambarkan kondisi keuangan perusahaan dari kondisi stabil. Menurut SAS No. 99, ketika stabilitas keuangan (financial stability) terancam oleh keadaan ekonomi, industri, dan situasi entitas yang beroperasi, manajer menghadapi tekanan untuk melakukan financial statement fraud. Dalam riset ini sebagaimana Skousen et.al (2008) melakukan perhitungan atas perubahan total aset degan rumus berikut:

Perubahan Total Aset $=\frac{\text { total asset } t-\text { total aset } t-1}{\text { total aset } t-1}$

Komponen Pressure (Tekanan) diukur melalui dua variabel kedua dengan Financial Leverage (Leverage Keuangan). Besarnya nilai financial leverage menunjukan pihak eksternal mendanai aktivitas perusahaan, semakin besar nilai leverage menunjukan perusahaan mampu mendapatkan pinjaman dari pihak eksternal untuk tetap berkompetitif sehingga menjauhi manajemen dalam melakukan financial statement fraud. Dalam riset ini sebagaimana Skousen et al (2008), untuk menghitung leverage menggunakan formula sebagai berikut :

Leverage $=\frac{\text { total hutang }}{\text { total aset }}$

Ketiga diukur dengan Financial Target (Target Keuangan). Return on Asset dijadikan sebagai proksi untuk variabel financial targets dalam penelitian ini. Return on Asset (ROA) merupakan bagian dari rasio profitabilitas dalam analisis laporan keuangan atau pengukuran kinerja perusahaan (Skousen dkk., 2008). Dalam riset ini sebagaimana Skousen et.al (2008) melakukan perhitungan ROA dengan rumus sebagai berikut:

ROA $\frac{\text { labasetelah pajak }}{\text { total aset }}=$

Keempat diukr dengan Capital (Modal); Persons (1999) menyatakan bahwa Capital Turn Over (perputaran modal) mengukur kemampuan manajemen dalam mengahadapi persaingan usaha selain itu Capital Turnover jugamenggambarkan tingkat kemampuan penjualan dibandingkan dengan aset perusahaan. Dalam riset ini sebagaimana Soselisa et al. (2008) mengukur besarnya Capital Turn Over suatu perusahaan dengan menggunakan rumus sebagai berikut:

Capital Turn Over $=\frac{\text { SALES }}{\text { TOTALASET }}$ 


\section{Opportunity (Peluang/ Kesempatan)}

Komponen Opportunity diukur melalui dua variabel, pertama dengan Nature of Industry (Keadaan Ideal Industri). Nature of Industry merupakan keadaan ideal suatu perusahaan dalam industri.Summers dan Sweeney (1998 dalam Skousen et al., 2008) mencatat bahwa akun piutang dan persediaan memerlukan penilaian subjektif dalam memperkirakan tidak tertagihnya piutang.Oleh karena itu, penelitian ini menggunakan Rasio Total Receivable untuk proksi Nature Receivable.

Nature Receivable $\quad \frac{\text { PIUTANGT }}{\text { PENJUALANT T }}-\frac{\text { PIUTANGT }-1}{\text { PENJUALAN T }-1}=$

Kedua diukur dengan Effective Monitoring (Keefektifan Pengawasan). Proporsi anggota dewan komisaris independen lebih besar memiliki tingkatan yang rendah dalam terjadinya fraud Beasly et al. (2002) dalam Skousen et al. (2009). Hal ini membuktikan bahwa proporsi anggota dewan komisaris independen mempengaruhi tingkatan fraud pada perusahaan. Effective monitoring diproksikan dengan IND.

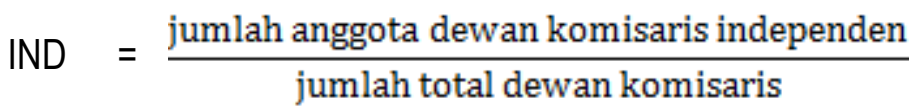

\section{Rationalization (Rasionalisasi)}

Opini Auditor dapat memberikan beberapa opini atas perusahaan yang diauditnya sesuai dengan kondisi yang terjadi pada perusahaan tersebut.Salah satu opini auditor yang diberikan adalah wajar tanpa pengecualian dengan bahasa pen jelas. Apabila perusahaan yang mendapat opini wajar tanpa pengecualian dengan bahasa penjelas selama periode 2013-2015 maka diberi kode 1 , dan apabila per usahaan yang mendapat selain opini tersebut maka diberi kode 0 .

Populasi dalam penelitian ini adalah semua perusahaan aneka industri yang listing di Bursa Efek Indonesia periode 2012- 2015, dengan jumlah populasi 41 Perusahaan, dengan Metode pengambilan sampel yang digunakan adalah metode purposive sampling.Sampel dalam penelitian ini dipilih berdasarkan criteria, sampel sebanyak 13 perusahaan.

\section{HASIL DAN PEMBAHASAN}

Uji normalitas bertujuan untuk menguji apakah dalam model regresi variabel penganggu atau residual memiliki distribusi normal (Ghozali, 2013). Cara untuk mendeteksi residual berdistribusi normal atau tidak adalah dengan melihat nilai signifikansi residual pada tabel OneSample Kolmogrov- Smirnov (K-S) .Jika nilai signifikansi lebih dari 0.05 maka residual terdistribusi secara normal.

Uji Multikolonieritas bertujuan untuk menguji apakah model regresi ditemukan adanya korelasi antar variabel bebas (independen). Untuk mendeteksi ada atau tidaknya multikolonieritas didalam model regresi yaitu dengan melihat nilai dari Tolerance dan Variance Inflation Factor (VIF). Jika nilai tolerance $\geq 0.10$ atau nilai nilai VIF $\leq 10$, berarti tidak terjadi multikolonieritas.

Uji Autokeorelasi bertujuan menguji apakah dalam model regresi linear ada korelasi antara kesalahan pengganggu pada periode $\mathrm{t}-1$ (sebelumnya) (ghozali, 2013). Run test digunakan untuk melihat apakah data residual terjadi secara random atau tidak (sistematis). 
Hasil output SPSS menunjukan bahwa Nilai test adalah -0.16859 dengan probabilitas 0.544 tidak signifikan pada 0.05 yang berarti hipotesis nol diterima. Maka dapat disimpulkan bahwa residual random (acak) atau tidak terjadi autokorelasi antar nilai residual dan penelitian dapat dilanjutkan.

Hasil Uji Heteroskedastisitas pada Model Regresi karena penelitian ini menggunakan uji statistic park untuk melihat apakah data penelitian terjadi heteroskedastisitas atau tidak. Hasil output SPSS dengan jelas menunjukan bahwa tidak ada satupun variabel independen yang signifikan secara statistic mempengaruhi variabel dependen nilai $\mathrm{Ln} U 2 \mathrm{i}\left(\mathrm{LnU}^{2} \mathrm{i}\right)$. Hal ini terlihat dari probabilitas signifikansinya diatas tingkat signifikan 0.05.Jadi dapat disimpulkan model regresi tidak mengandung adanya heterokedastisitas sehingga analisis dapat dilanjutkan.

\section{HASIL DAN PEMBAHASAN}

Hasil Uji Parsial (Uji t) menunjukan secara parsial financial stability memiliki tingkat signifikansi yakni 0.112> 0.05 dan nilai thitung $1.627<$ tabel 2.02619, maka dapat disimpulkan financial stability tidak berpengaruh secara signifikan terhadap financial statement fraud. Untuk variabel financial leverage memiliki tingkat signifikansi yakni $0.000<0.05$ dan nilai nilai t hitung $5.426>$ t tabel 2.02619 sehingga dapat disimpulkan

1. Financial Leverage berpengaruh secara signifikan terhadap financial statement fraud. Secara parsial variabel financial target memiliki tingkat signifikansi yakni $0.006<0.05$ dan nilai thitung $-2.890>$ tabel 2.02619 sehingga $\mathrm{H}_{\mathrm{o}}$ ditolak dan menerima $\mathrm{H}_{\mathrm{a}}$, maka dapat disimpulkan financial target berpengaruh secara signifikan terhadap financial statement fraud. Tabel 4.5

2. Capital memiliki tingkat signifikansi yakni $0.000<0.05$ dan nilai thitung $12.489<$ tabel $_{\text {tab }} 2.02619$ sehingga $\mathrm{H}_{\mathrm{a}}$ diterima dan menolak $\mathrm{H}_{\mathrm{o}}$ maka dapat disimpulkan capital berpengaruh secara signifikan terhadap financial statement fraud.

3. Nature Of Industry tidak berpengaruh secara signifikan terhadap financial statement fraud, begitu pula variabel financial target dan variabel opini audit tidak berpengaruh secara signifikan terhadap financial statement fraud.

Tabel 1. Hasil Uji T

Coefficients $^{a}$

\begin{tabular}{|c|c|c|c|c|c|}
\hline \multirow[t]{2}{*}{ Model } & \multicolumn{2}{|c|}{$\begin{array}{c}\text { Unstandardized } \\
\text { Coefficients }\end{array}$} & $\begin{array}{l}\text { Standardized } \\
\text { Coefficients }\end{array}$ & \multirow[t]{2}{*}{$t$} & \multirow[t]{2}{*}{ Sig. } \\
\hline & B & Std. Error & Beta & & \\
\hline (Constant) & .038 & .916 & & .041 & .967 \\
\hline X1 & 1.725 & 1.060 & .100 & 1.627 & .112 \\
\hline $\mathrm{X} 2$ & -4.471 & .824 & -.438 & -5.426 & .000 \\
\hline${ }_{1} \times 3$ & -11.229 & 3.885 & -.255 & -2.890 & .006 \\
\hline$X 4$ & 5.096 & .408 & 1.132 & 12.489 & .000 \\
\hline$\times 5$ & -.150 & .399 & -.023 & -.377 & .709 \\
\hline X6 & -1.020 & 1.721 & -.038 & -.593 & .557 \\
\hline $\mathrm{X} 7$ & .395 & .338 & .074 & 1.168 & .250 \\
\hline
\end{tabular}

a. Dependent Variable: $Y$

Sumber Output SPSS 
Hasil Uji Simultan (Uji F) berdasarkan tabel 2. dibawah dapat dilihat bahwa secara simultan variabel independen memilki signifikansi $0.000<0.05$ dan nilai $F_{\text {hitung }} 37.102>F_{\text {tabel }} 2.35$. Maka $\mathrm{H}_{\mathrm{a}}$ diterima, jadi secara simultan variabel independen berpengaruh secara signifikan terhadap variabel dependen.

Tabel 2. Hasil Uji F

ANOVAa $^{a}$

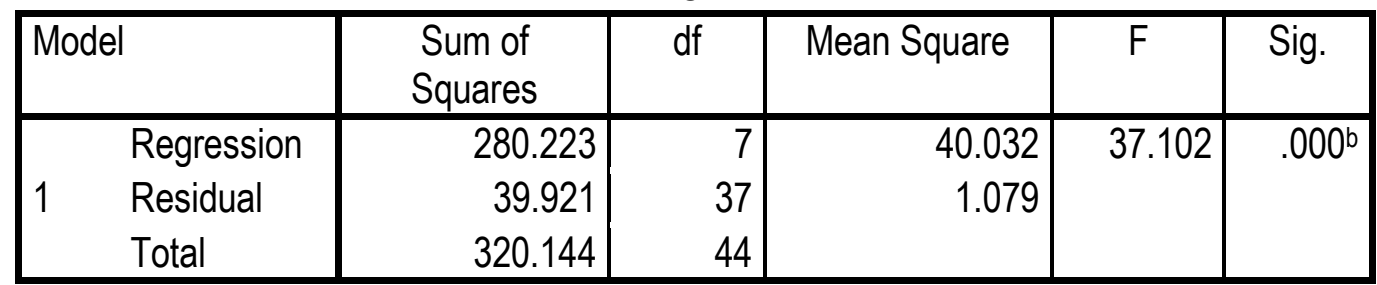

a. Dependent Variable: $Y$

b. Predictors: (Constant), X7, X5, X1, X2, X6, X3, X4

Sumber Output SPSS

Hasil Uji Koefisien Determinansi (Adjusted $R$ Square), berrdasarkan Tabel 3 dibawah, dapat dilihat angka koefisien determinasi yakni 0.852 atau $85.2 \%$. Hal ini menunjukan bahwa variabel independen berupa financial stability, financial leverage, financial target, capital, nature of industry, effective monitoring, dan opini auditor dapat menjelaskan variabel dependen financial statement fraud sebesar $85.2 \%$ dan sisanya $14.8 \%$ dijelaskan oleh variabel- variabel lain diluar penelitian ini.

Tabel 3. Koefisien Determinasi (Adjusted R²)

Model Summaryb

\begin{tabular}{|l|l|r|r|r|}
\hline Model & R & R Square & Adjusted R Square & Std. Error of the Estimate \\
\hline 1 & $.936 \mathrm{a}$ & .875 & .852 & 1.038727852024 \\
\hline
\end{tabular}

a. Predictors: (Constant), X7, X5, X1, X2, X6, X3, X4

c. Dependent Variable: $Y$

Sumber Output SPSS

Analisis Regresi Berganda diuji berdasarkan analisis hasil penelitian didapatkan semua variabel independen mempunyai pengaruh yang signifikan terhadap variabel dependen financial statement fraud. Maka persamaan regresi sebagai berikut :

FRAUD $=0.038+1.725$ ACHANGE -4.471 LEV -11.229 ROA +5.096 CATO -0.150 RECEIVABLE - 1.020 IND+ 0.395 OPINI $+\varepsilon$

\section{Pembahasan}

Hasil pengujian regresi financial stability (ACHANGE) memilki tingkat signifikansi yaitu 0.112 $>0.05$. Maka dapat disimpulkan bahwa financial stabilitytidak berpengaruh secara signifikan terhadap financial statement fraud.Hal ini mendukung penelitian Yesiriani et.al (2016). Financial stability dapat tidak mempengaruhi financial statement fraud ketika mempunyai tingkat pengawasan sangat baik yang dilakukan oleh Dewan Komisaris untuk memonitor dan mengendalikan tindakan manajemen yang bertanggung jawab langsung terhadap fungsi bisnis seperti keuangan, sehingga walaupun menajemen menghadapi tekanan ketika stabilitas 
keuangan terancam oleh keadaaan ekonomi, industri dan situasi entitas yang beroperasi tidak akan mempengaruhi terjadi kecurangan laporan keuangan.

Hasil pengujian regresi financial leverage (LEV) memilki tingkat signifikansi yaitu $0.000<$ 0.05.Maka dapat disimpulkan bahwa financial leverage berpengaruh secara signifikan terhadap financial statement fraud. Hal ini mendukung penelitian Manurung et.al (2014) dan Tifany (2014).

Hasil penelitian ini menunjukan bahwa financial leverage berpengaruh signifikan terhadap financial statement fraud, hal tersebut terjadi dikarenakan manajemen merasa tertekan untuk mendapatkan pinjaman hutang kepada pihak luar agar perusahaan tetap dapat berkompetitif dengan perusahaan lainnya dan meningkatkan tingkat terjadinya financial statement fraud.

Hasil pengujian regresi financial target (ROA) memiliki tingkat signifikansi yaitu $0.006<0.05$. Maka dapat disimpulkan bahwa financial target berpengaruh secara signifikan terhadap financial statement fraud. Hal ini mendukung penelitianYesiriani (2016). ROA aktual yang tinggi yang telah dicapai menunjukkan bahwa profitabilitas juga tinggi yang artinya target perusahaan tercapai. Sehingga mengurangi manajemen untuk melakukan tindakan fraud menjadi tinggi.Apabila ekspektasi untuk mempertahankan atau memperbaiki tingkat profitabilitas masa lalu tidak dapat dipenuhi oleh kinerja aktualnya, sehingga hal ini memberikan motivasi bagi adanya financial statement fraud.

Hasil pengujian regresi capital (CATO) memilki tingkat signifikansi yaitu $0.000<0.05$.Maka dapat disimpulkan bahwa capital berpengaruh secara signifikan terhadap financial statement fraud.Hal ini mendukung penelitian Kara et.al (2013). Semakin besar nilai penjualan memberikan tekanan kepada pihak manajemen untuk lebih meningkatkan lagi penjualan di tahun berikutnya, sehingga menyebabkan semakin tingginya terjadi financial statement fraud yang dilakukan manajemen. Ketika suatu perusahaan tidak dapat mempertahankan aktivitas penjualannya maka perusahaan dapat melakukan fraud dengan cara memanfaatkan aset perusahaan untuk menghasilkan pendapatan.

Hasil pengujian regresi nature of industry (RECEIVABLE) memilki tingkat signifikansi yaitu 0.709> 0.05.Maka dapat disimpulkan bahwa nature of industry tidak berpengaruh secara signifikan terhadap financial statement fraud. Hal ini berarti menunjukkan hipotesis ditolak, karena nilai rata-rata perubahan piutang perusahaan dari tahun sebelumnya tidak berpengaruh terhadap perputaran kas perusahaan.Banyaknya piutang usaha yang dimiliki perusahaan tidak mengurangi jumlah kas yang dapat digunakan perusahaan untuk kegiatan operasionalnya sehingga rasio perubahan dalam piutang usaha tidak memicu manajemen untuk melakukan kecurangan laporan keuangan.

Hasil pengujian regresi effective monitoring (IND) memilki tingkat signifikansi yaitu 0.557> 0.05.Maka dapat disimpulkan bahwa effective monitoring tidak berpengaruh secara signifikan terhadap financial statement fraud, hal ini mendukung penelitianYesiriani et.al (2016). Fraud dapat diminimalkan dengan pengawasan yang baik, namun dalam hal ini hipotesis ditolak, karena kemungkinan keberadaan dewan komisaris independen akan memberikan sedikit jaminan bahwa pengawasan perusahaan akan semakin independen dan objektif serta jauh dari intervensi pihak- pihak tertentu. Fraud dapat diminimalkan salah satunya dengan mekanisme pengawasan yang baik.Keberadaan dewan komisaris independen dalam suatu perusahaan merupakan suatu faktor yang signifikan dalam peningkatan pengawasan operasional perusahaan.

Hasil pengujian regresi opini auditor (OPINI) berupa opini wajar tanpa pengecualian dengan bahasa penjelas memilki tingkat signifikansi yaitu 0.250>0.05. Maka dapat disimpulkan bahwa opini auditor berupa opini wajar tanpa pengecualian dengan bahasa penjelas tidak berpengaruh 
secara signifikan terhadap financial statement fraud.Hal ini mendukug penelitian Anisya et.al (2014).

\section{Kesimpulan}

Penelitian ini bertujuan untuk menganalisis pengaruh antara financial stability, external pressure, financial target, capital, nature of industry, effective monitoring, dan opini auditor terhadap financial statement fraud. Berdasarkan hasil penngujian regresi linier berganda yang digunakan, dapat ditarik kesimpulan sebagai berikut:

1. Financial Stability berpengaruh secara signifikan terhadap financial statement fraud.

2. Financial Leverage berpengaruh secara signifikan terhadap financial statement fraud.

3. Financial Target tidak berpengaruh secara signifikan terhadap financial statement fraud.

4. Capital berpengaruh secara signifikan terhadap financial statement fraud.

5. Nature of Industry tidak berpengaruh secara signifikan terhadap financial statement fraud.

6. Effective Monitoring tidak berpengaruh secara signifikan terhadap financial statement fraud.

7. Opini Auditor tidak berpengaruh secara signifikan terhadap financial statement fraud.

8. Secara simultan financial stability, financial leverage, financial target, capital, nature of industry, effective monitoring dan, opini auditor memilki pengaruh secara signifikan terhadap financial statement fraud.

\section{DAFTAR PUSTAKA}

Standar Akuntansi". Jakarta: Citra Harta Prima.

Arthur, J. Keown dan John, D Martin. 2010. "Manajemen Keuangan: Prinsip dan Penerapan Jilid 2". Jakarta : Indeks

Asward, Ismalia dan Lina. 2013. Pengaruh Mekanisme Corporate Governance terhadap Manajemen Laba dengan Pendekatan Conditional RevenueModel.Universitas Pelita Harapan.

Christy, Issabella Marsasella, Sugito dan Abdul, Hoyyi. 2015. Penerapan Formula Beniesh MScore Dan Analisis Diskriminan Linier Untuk Klasifikasi Perusahaan Manipulator Dan Nonmanipulator (Studi Kasus Di Bursa Efek Indonesia Tahun 2013).Universitas Diponegoro. ISSN: 2339-2541 Jurnal Gaussian, Volume 4, Nomor 2, Tahun 2015, Halaman 287 - 293.

Ghozali, Imam.2013. Aplikasi Analisis Multivariate dengan Program IBM SPSS 21. Semarang: Badan Penerbit Universitas Diponegoro.

Hery. 2013. "Teori Akuntansi Suatu Pengantar". Jakarta: Fakultas Ekonomi Universitas Indonesia.

Irham, Fahmi. 2012. "Analisis Laporan Keuangan". Bandung: Alfabeta.

Kara, Suat dan Yereli,Ayse N.2013.Effectiveness of the Financial Ratios in the Determination of the Fraudulent Financial Statements: Turkey Practice. Journal of Modern Accounting and Auditing. ISSN 1548-6583 October 2013, Vol. 9, No. 10, 1342-1353.

Lou, Yung-i and Ming-Long, Wang. 2009. Fraud Risk Factor of the Fraud Triangle Assessing the Likelihood of Fradulent Financial Reporting. Journal of Business \& Economics Research Vol. 7 No. 2.

Maghfiroh, Nur, Ardiyani, Komala dan Syafnita. 2015. AnalisisPengaruh Financial Staability, Personal Financial Need, External Pressure, Danlneffective Monitoring Pada Financial 
Statement Fr. Dalam Perspektif Fraud. Universitas Pekalongan. Jurnal Ekonomi dan Bisnis.Volume 16. Nomor 01.Maret 2015.

Manurung, Daniel T.H dan Hadian, Niki.2013.Detection Fraud Of Financial Statement with Fraud Triangle. Proceedings of 23rd/nternational Business Research Conference 18- 20 November, 2013, Marriot Hotel, Melbourne, Australia, ISBN: 978-1-922069-36-8.

Martantya, Daljono. 2013. Pendeteksian Kecurangan Laporan Keuangan Melalui Faktor Risiko Dan Peluang (Studi Kasus pada Perusahaan yang Mendapat Sanksi dari Bapepam Periode 2002-2006). DIPONEGORO JOURNAL OFACCOUNTING Volume2, Nomor 2, Tahun 2013, Halaman1-12 http://ejournal-s1.undip.ac.id/index.php/accounting ISSN(Online): 2337-3806

Messod D, Beneish 1999. "The Detection of Earnings Manipulation". Article in Financial Analysts Journal, September 1999.

Mulyadi.Auditing. Buku 1 edisi 6 Jakarta: PT Salemba empat, 2004.

Nooraslinda, Abdul Aris, Rohana Othman, Siti Maznah Mohd Arif, Mohamad Affendi Abdul Malek dan Normah.2013. Fraud Detection: Benford's Law vs Beneish Model. IEE Symposium on Humanities, Science ang Engineering Research.

Parasmita, Ananda A.2014. Pengaruh Kefektifan Pengendalian Iternal Dan Kepuasan Kerja Terhadap Kecendrungan Kecurangan Akuntansi Pada Dinas Pendapatan Dan PengelolaanAset Daerah Istimewa Yogyakarta.Jurnal Nominal/ Volume III Nomor 1.

Person, Obeua. 1999. Using Financial Information to Differentiate Failed vs Surviving Finance Companies in Thailand: An Implication for Emerging Economies. Multinational Finance Journal.Vol. 3. No.2. pp.127145.

Priantara, Diaz. 2013. "Fraud Auditing \& Investigation". Jakarta: Mitra Wacana Media.

Riahi, Ahmed dan Belkaoul. 2006. "Buku Satu Accounting Theory Edisi Lima". Jakarta: Salemba Empat.

Siregar, Sofyan.2013. "Metode Penelitian Kuantitatif Dilengkapi Dengan Perbandingan Perhitungan Manual \& SPSS". Jakarta: Prenamedia Group.

Skousen, J.C., Wright, J.C., Smith Kevin, R. 2008, "Detecting and Predicting Financial Statement Fraud: The Effectiveness of the Fraud Triangle and SAS No. 99." Advances in Financial Economics Vol. 12 No.1.

Soselisa, Rangga dan Mukhlasin.2009.Pengaruh Faktor Kultur Organisasi, Manajemen, Strategik, Keuangan dan Auditor Terhadap Kecendrungan Kecurangan Akuntansi: Studi Pada Perusahaan Publik di Indonesia. UNIKA Atmajaya- Jakarta.

Sugiyono. 2015. "Metode Penelitian Manajemen". Bandung: Alfabeta.

Sukirman dan Maylia, Pramono Sari. 2013. Model Deteksi Kecurangan BerbasisFraud Triangle (Studi Kasus Pada Perusahaan Publik Di Indonesia).Universitas Negeri Semarang.Jurnal Akuntansi \& Auditing Volume 9/No. 2/MEI 2013 : 199 - 225

Sunyoto, Danang. 2011. "Analisis Regresi dan Uji Hipotesis". Yogyakarta: CAPS.

Thoyibatun, Siti.2009."Faktor- Faktor Yang Berpengaruh Terhadap Perlaku Tidak Etis Dan Kecendrungan Kecuranga Akuntansi Serta Akibatnya Terhadap Kinerja Organisasi".Ekuitas: Jurnal Ekonomi dan Keuangan Akreditasi No. 110/DIKTI/Kep/2009 ISSN 1411-0393.

Tiffani, Laila dan Marfuah.2014"Deteksi Financial Statement Fraud dengan Analisis Fraud Triangle Pada Perusahaan Manufaktur yang Terdaftar Di Bursa Efek Indonesia". Universitas Islam Indonesia.

Tunggal, Amin Widjaja. 2011. "Teori Dan Kasus Kecurangan Akuntansi Dan Keuangan". Jakarta: Harvarindo. 
Yesiariani, Merissa dan Rahayu, Isti.2016.Analisis Fraud Diamond Dalam Mendeteksi Financial Statement Fraud (Studi Empiris pada Perusahaan LQ-45 yang Terdaftar di Bursa Efek Indonesia Tahun 2010 - 2014). Simposium Nasional Akuntansi XIX, Lampung.

Yudhanti, Nindya Carla dan Suryandari, Erni.2016.Faktor - Faktor Yang Mempengaruhi Indikasi Kcurangan Dalam Pelaporan Keuangan Dengan Model Fraud Diamond (Studi Empiris Pada Perusahaan Manufaktur yang Terdaftar di Bursa Efek Indonesia periode 20132015).Universitas Muhamaddiyah Yogyakarta.

Zakaria, Heikal Muhammad dan Nurbaiti, Anisa.2016.Pengaruh Fraud Risk Factor Terhadap Pendeteksian Kemungkinan Fraudlent Financial Statement.Vol. 1 No.01 2016. 
Deteksi Financial Statement Fraud Dengan Analisis Fraud Triangle

Pada Perusahaan Aneka Industri Yang Terdaftar Di Bursa Efek Indonesia Periode 2012- 2015"

Hal. 36 